Ambiente \& Água - An Interdisciplinary Journal of Applied Science
ISSN 1980-993X - doi:10.4136/1980-993X
www.ambi-agua.net
E-mail: ambi.agua@gmail.com

\title{
Deproteinization: an integrated-solution approach to increase efficiency in $\beta$-galactosidase production using cheese whey powder (CWP) solution
}

\author{
doi:10.4136/ambi-agua.1936
}

Received: 09 May 2016; Accepted: 08 Jun. 2017

\author{
Leandro Freire dos Santos ${ }^{1 *}$; Cibely Maria Gonçalves ${ }^{2}$; \\ Priscila Lumi Ishii $^{3}$; Hélio Hiroshi Suguimoto \\ ${ }^{1}$ Universidade Estadual do Centro-Oeste (UNICENTRO), Guarapuava, PR, Brasil \\ Departamento de Farmácia \\ ${ }^{2}$ Universidade Norte do Paraná (UNOPAR), Londrina, PR, Brasil \\ Programa de Pós-Graduação em Ciência e Tecnologia de Leite e Derivados \\ ${ }^{3}$ Universidade Estadual do Centro-Oeste (UNICENTRO), Guarapuava, PR, Brasil \\ Departamento de Nutrição \\ "Corresponding author: e-mail: leandrofreire@onda.com.br, \\ cibely.maria431@gmail.com,pri_ishii@hotmail.com, helio.suguimoto@unopar.br
}

\begin{abstract}
Whey is the liquid that results from the coagulation of milk during cheese manufacture. Cheese whey is also an important environmental pollution source. The present experiment sought to compare $\beta$-galactosidase (EC 3.2.1.23) production by Aspergillus oryzae from deproteinized and un-deproteinized CWP solutions. $\beta$-galactosidase was produced by submerged fermentation in deproteinized or un-deproteinized CWP solutions. To determine the activity of the enzyme, a reaction mixture containing cell-free extract and ortho-Nitrophenyl- $\beta$-galactoside (ONPG) was used. The results indicated that $\beta$-galactosidase induction was greater when using deproteinized CWP solution compared to the un-deproteinized CWP solution. These results may enable an alternative management of cheese whey, thereby decreasing its impact on the environment and producing value-added biomacromolecules.
\end{abstract}

Keywords: cheese whey, deproteinization, $\beta$-galactosidase.

\section{Desproteinização: uma abordagem de solução integrada para aumentar a eficiência na produção de $\beta$-galactosidase usando solução à base de soro de queijo em pó}

\section{RESUMO}

O soro de queijo é o líquido resultante da coagulação do leite durante a manufatura do queijo. Em adição, o soro de queijo é uma importante fonte de poluição ambiental. O principal objetivo do presente experimento foi comparar a produção de $\beta$-galactosidase (EC 3.2.1.23) por Aspergillus oryzae a partir de uma solução de soro de queijo desproteinizada e nãodesproteinizada por fermentação submersa. Para se determinar a atividade enzimática, um meio reacional contendo extrato livre de células e orto-nitrofenol- $\beta$-galactosídeo (ONPG) foi usado. 
Os resultados indicaram que a indução de $\beta$-galactosidase foi maior quando usada solução de SQP desproteinizada comparada à solução não-desproteinizada. Estes resultados podem permitir uma gestão alternativa do soro de queijo, diminuindo assim seu impacto no ambiente e produzindo biomacromoléculas de valor agregado.

Palavras-chave: soro de queijo, desproteinização, $\beta$-galactosidase.

\section{INTRODUCTION}

The dairy industry produces high amounts of wastewater, of which cheese whey is the most important. Cheese whey disposal is challenging issue from an environmental standpoint due to its high organic load (lactose content). An estimated chemical oxygen demand of $60-80 \mathrm{~kg} / \mathrm{m}^{3}$ and biological oxygen demand of $35-45 \mathrm{~kg} / \mathrm{m}^{3}$ are required to oxidize the organic matter via oxidative phosphorylation. Moreover, world production of cheese whey is $10^{8} \mathrm{t}$ per year (Bosso et al., 2016; Colognese et al., 2015; Moreira et al., 2015).

In turn, lactose can be hydrolyzed using acid treatments or enzymatic catalysis by the enzyme $\beta$-galactosidase. In this last treatment, $\beta$-galactosidase hydrolysis of terminal nonreducing $\beta$-D-galactose residues in $\beta$-D-galactosides. In addition, this enzyme can be obtained mainly by bioprocess via the induction method (Aspergillus oryzae and Escherichia coli), and it can also be found constitutively in bovine livers and testes (Fan et al., 2016; Kroeger and Thiem, 2007; Yan et al., 2014). Interestingly, after the downstream process, $\beta$-galactosidase can be applied industrially to obtain lactose-free products which can be consumed by lactose-intolerant individuals (Bosso et al., 2016). These individuals frequently have abdominal bloating and cramps, diarrhea, flatulence, nausea and vomiting due to their inability to digest lactose (Savaiano et al., 2013).

Recently, Aspergillus oryzae was evaluated for its ability to induce proteases which could consequently provide amino acids for energy functions (Murthy et al., 2015). Thus, in view of the importance of obtaining $\beta$-galactosidase mainly by the induction method (high yields), it was hypothesized that the deproteinization of cheese whey could promote high $\beta$-galactosidase induction in order to maintain the chemical energy levels which were previously provided by proteins. Interestingly, albumin energy contribution (ATP content) to the viability of cell cultures had already been evaluated (Suzuki et al., 2016).

In this article, deproteinization has been implemented in cheese whey management to evaluate its effect on production of $\beta$-galactosidase. These data might be useful in optimizing enzyme production and other value-added products.

\section{MATERIALS AND METHODS}

\subsection{Microorganism and Growth}

Aspergillus oryzae was obtained from the Centre for Postgraduate Studies and Research, University of Northern Paraná, and was maintained in tubes containing potato dextrose agar. For sporulation, fungus was grown in Petri dishes for 15 days at $30^{\circ} \mathrm{C}$. All reagents used were of the highest grade available. All the media were autoclaved at $121^{\circ} \mathrm{C}$ at $15 \mathrm{~min}$. The cultures were kept at $4^{\circ} \mathrm{C}$ and renewed once in four weeks (Miyake et al., 2007).

\subsection{Media and Culture Conditions}

$\beta$-galactosidase was produced using a submerged fermentation in $250 \mathrm{~mL}$ Erlenmeyer flasks. The inoculum was prepared at a concentration of $10^{6}$ spores $\mathrm{mL}^{-1}$, and the fermentation was maintained at $30^{\circ} \mathrm{C}, 100 \mathrm{rpm}$ for 7 days. Basal fermentation medium (BFM) was prepared 
using yeast extract $(12 \mathrm{~g} / \mathrm{L}),\left(\mathrm{NH}_{4}\right)_{2} \mathrm{SO}_{4}(6.0 \mathrm{~g} / \mathrm{L}), \mathrm{KH}_{2} \mathrm{PO}_{4}(5.0 \mathrm{~g} / \mathrm{L})$ and $\mathrm{MgSO}_{4} .7 \mathrm{H}_{2} \mathrm{O}$ $(0.6 \mathrm{~g} / \mathrm{L})$. Whey powder obtained from CONFEPAR (Agro-Industrial Cooperative) at Londrina-PR, Brazil was used for the CWP solutions $(1,5,10 \% \mathrm{w} / \mathrm{v}-\mathrm{g} / \mathrm{L})$. Deproteinization was executed under the following conditions: $\mathrm{pH} 4.8$ (adjusted with lactic acid) at $95^{\circ} \mathrm{C}$ followed by centrifugation to remove the protein fraction (1500 g for 15 minutes). The production kinetics of microorganisms was measured in Erlenmeyer flasks using the optimum conditions for the production of $\beta$-galactosidase. Aliquots were removed every $24 \mathrm{~h}$ (Colognese et al., 2015; Moreira et al., 2015).

\subsection{Analytical methods}

Fresh biomass was obtained from the submerged cultures by a $10^{6} \mathrm{~nm}$ filter mesh size. $\mathrm{pH}$ was determined by potentiometry. Lactose was quantified according to the phenol-sulfuric acid method (Araujo et al., 2015).

The whey powder underwent physicochemical analysis at CONFEPAR's quality control laboratory to determine the components of interest for the present study): water content (\%), total protein $(\%), \mathrm{pH}$, lactose $(\mathrm{mg} / \mathrm{g})$, ash $(\mathrm{mg} / \mathrm{g})$, antibiotic, fat $(\%)$, specific weight $\left(\mathrm{g} / \mathrm{cm}^{3}\right)$, presence of burnt particles, titratable acidity (\%), and insolubility index. The analyses were performed according to procedures described by the Association of Analytical Communities (AOAC, 2005). Samples also were evaluated for the presence of Salmonella spp., Bacillus cereus, molds and yeasts, Staphylococcus coagulase positive, thermotolerant and total coliforms and mesophilic plate count (bacteriological and mycological analyses). The counts were obtained in triplicate according to the methodology described in Desconsi et al. (2014).

\section{4. $\beta$-galactosidase enzyme assay}

To determine the activity of the enzyme, the reaction mixture contained $10 \mu \mathrm{L}$ of cell-free extract and $10 \mathrm{nmol} / \mathrm{L}$ ONPG (ortho-Nitrophenyl- $\beta$-galactoside) in $1000 \mu \mathrm{L} \mathrm{K}_{2} \mathrm{HPO}_{4}-\mathrm{KH}_{2} \mathrm{PO}_{4}$ buffer $(0.1 \mathrm{~mol} / \mathrm{L}, \mathrm{pH} 6.5)$. The mixture was incubated at $40^{\circ} \mathrm{C}$ for $10 \mathrm{~min}$, and the reaction was stopped by the addition of $100 \mu \mathrm{L}$ of $\mathrm{Na}_{2} \mathrm{CO}_{3}(1 \mathrm{~mol} / \mathrm{L})$. The hydrolysis of the $o$-nitrophenol (oNP) group was then detected by $405 \mathrm{~nm}$. One unit of enzyme activity is defined as the amount of $1 \mathrm{~mol} / \mathrm{L}$ oNP liberated per minute under the standard reaction conditions (International units-U).

\subsection{Statistical analysis}

Statistical analyses were performed using the GraphPad Prism ${ }^{\circledR}$. A normality test was previously used to determine if the data set was well-modeled by a normal distribution. The data are presented as mean \pm standard error of the mean (SEM) values. Statistical analysis was performed by one-way ANOVA, followed by the Tukey test $(\mathrm{p}<0.05)$ (Pacheco et al., 2015).

\section{RESULTS AND DISCUSSION}

This study evaluated the deproteinization technique during $\beta$-galactosidase production using cheese whey. Before the fermentation assays, microbiological analyses of CWP did not detect pathogenic agents, and the physicochemical composition was in accordance with international standards (Table 1). Among the nine mediums tested, two mediums exhibited notable ability to induce $\beta$-galactosidase, in which a medium composed of a $5 \%$-deproteinized CWP solution and of another composed of a 10\%-deproteinized CWP solution (Figure 1). These same mediums showed that when deproteinization was not inserted previously during the preparation of the culture medium (via protein isoelectric point and continuous flow autoclave process), the enzyme activity significantly decreased to below $85 \%$. Interestingly, Aspergillus oryzae has a known capacity to induce proteases, and consequently can provide amino acids for energy functions (Murthy et al., 2015). Thus, the absence of chemical energy 
from proteins due to the insertion of the deproteinization procedure has promoted high $\beta$-galactosidase induction to maintain the energy requirements. Concerning the CWP concentration, the $10 \% \mathrm{CWP}$ solution showed a lower capacity to induce $\beta$-galactosidase compared to the 5\% CWP solution. This might be due to increased osmotic stress caused by lactose in that formulation. Otherwise, a higher concentration of these dispersed solids would promote a non-Newtonian behavior that hinders transport phenomena such as oxygen diffusion and soluble solids (Duran et al., 2016; Malakar et al., 2014). Moreover, it was noted that components from the BFM had an inhibitory effect on enzyme activity in the BFM plus CWP formulations compared with those having only the CWP solution (Figure 1). Interestingly, previous studies showed that $\beta$-galactosidase activity and the total phosphorus present in BFM had a significant negative relationship (De Santiago-Martin et al., 2013). This behavior could be attributed to the regulation mechanisms of enzyme production by means of feedback processes.

Table 1. Physicochemical composition of whey.

\begin{tabular}{lc}
\hline Component & average \pm standard deviation \\
\hline Water content $(\%)$ & $1.90 \pm 0.10$ \\
Total protein $(\%)$ & $12.03 \pm 0.08$ \\
$\mathrm{pH}$ & $6.43 \pm 0.03$ \\
Lactose $(\mathrm{mg} / \mathrm{g})$ & $73.20 \pm 0.08$ \\
Ash $(\mathrm{mg} / \mathrm{g})$ & $5.89 \pm 0.07$ \\
Antibiotic & Negative \\
Fat $(\%)$ & $0.50 \pm 0.01$ \\
Specific weight $\left(\mathrm{g} / \mathrm{cm}^{3}\right)$ & $0.67 \pm 0.01$ \\
Presence of burnt particles & Disc A \\
Titratable acidity $(\%$ lactic acid $)$ & $0.09 \pm 0.01$ \\
Insolubility index & $0.30 \pm 0.10$ \\
\hline
\end{tabular}

Both treatment methods - filtration and centrifugation - were efficient to obtain a cell-free culture liquid during the kinetic of enzymatic activity under optimal conditions (5\%-deproteinized CWP solution), and lactose content was practically consumed from the medium $(0.5 \mathrm{~g} / 100 \mathrm{~mL})$ (Figure 2). Thus, it can be concluded that there was no influence of particle-network strength (via specific energy of cohesion) between the enzyme and liquid phases, nor did the viscoelastic state of the fermented medium negatively interfere with enzyme separation (Dandouh et al., 2016). Moreover, the final lactose content observed in batch fermentation is likely to result in a decrease of chemical oxygen demand, which indicates the amount of oxygen required to oxidize an organic compound to carbon dioxide (Colognese et al., 2015; Moreira et al., 2015). 


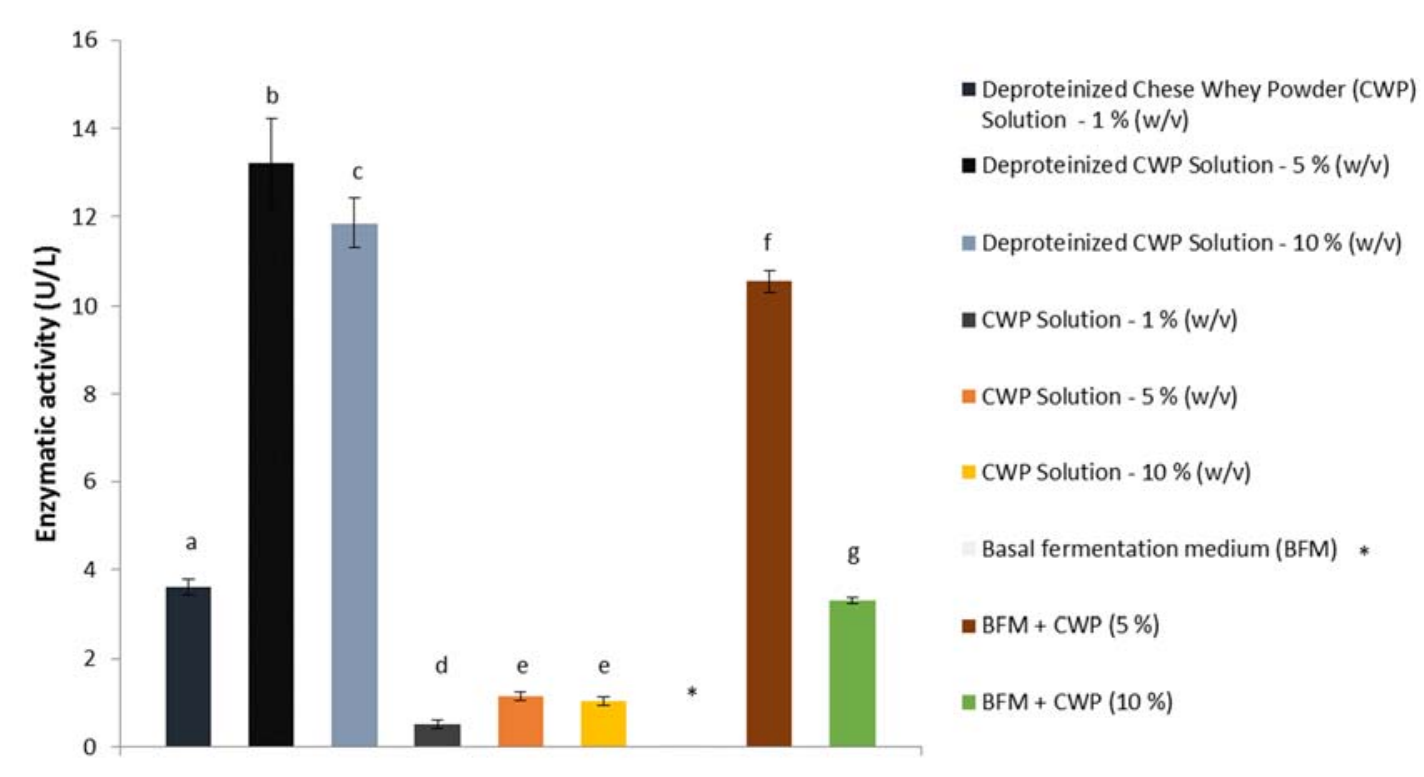

Figure 1. Effect of different culture media on the enzymatic activity of $\beta$-galactosidase from Aspergillus oryzae. Columns with different letters indicate significant differences at $\mathrm{p}<0.05$ (Tukey test).

Figure 3 shows the evolution of fresh biomass and $\mathrm{pH}$ under optimal conditions (5\%-deproteinized CWP solution). The biomass reached approximately $500 \mathrm{~g} / \mathrm{L}$ and the acidification was consistent with the fermentation process. Although the use of a demineralized version of 5\% CWP solution showed a similar profile as fresh biomass and $\mathrm{pH}$ evolution from integral CWP (Figures 3 and 5), the enzymatic activity of $\beta$-galactosidase decreased $75 \%$ (Figure 4). Delightfully, cheese whey can include the following minerals: calcium, copper, iron, magnesium, manganese, phosphorus, potassium, selenium, sodium and zinc (Tunick et al., 2015). Other previous studies showed that calcium, copper, magnesium and zinc are not needed as cofactors to beta-galactosidase (Lee et al., 2003). Thus, the initial comments concerning the negative relationship between phosphorus content and the enzymatic activity of beta-galactosidase again corroborate these results.

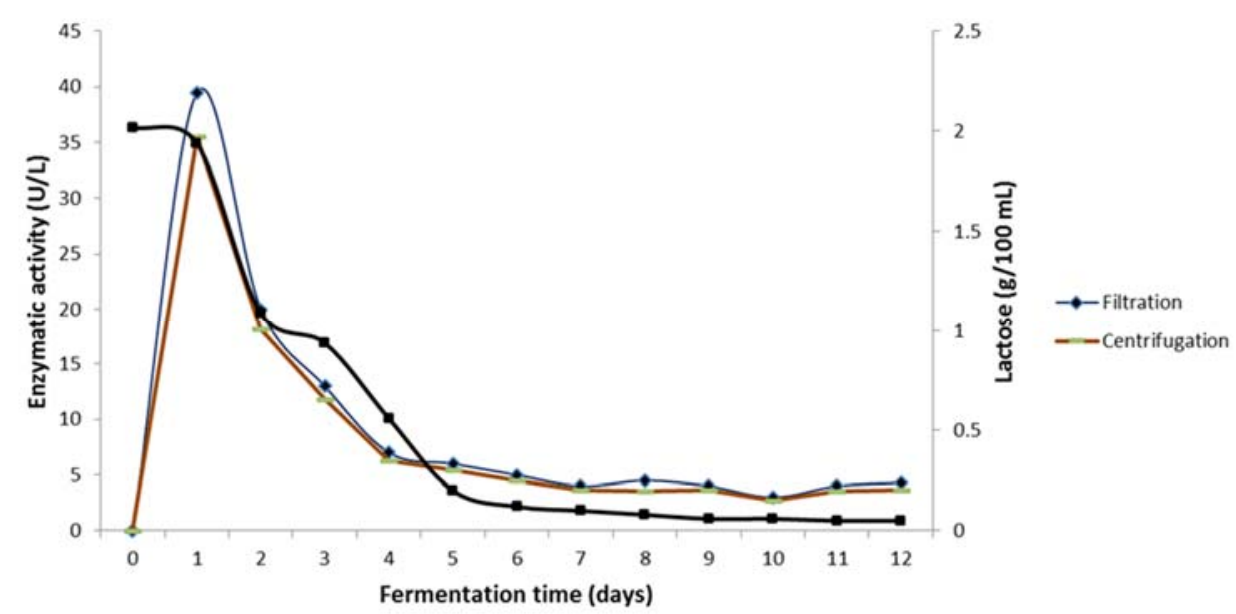

Figure 2. Evolution of enzymatic activity of $\beta$-galactosidase from Aspergillus oryzae and lactose content (filled square) during batch submerged fermentation (deproteinized CWP solution - 5\%). The fermentation medium was filtrated (filled diamond) and centrifuged (gray line) to obtain a cell free culture liquid. 


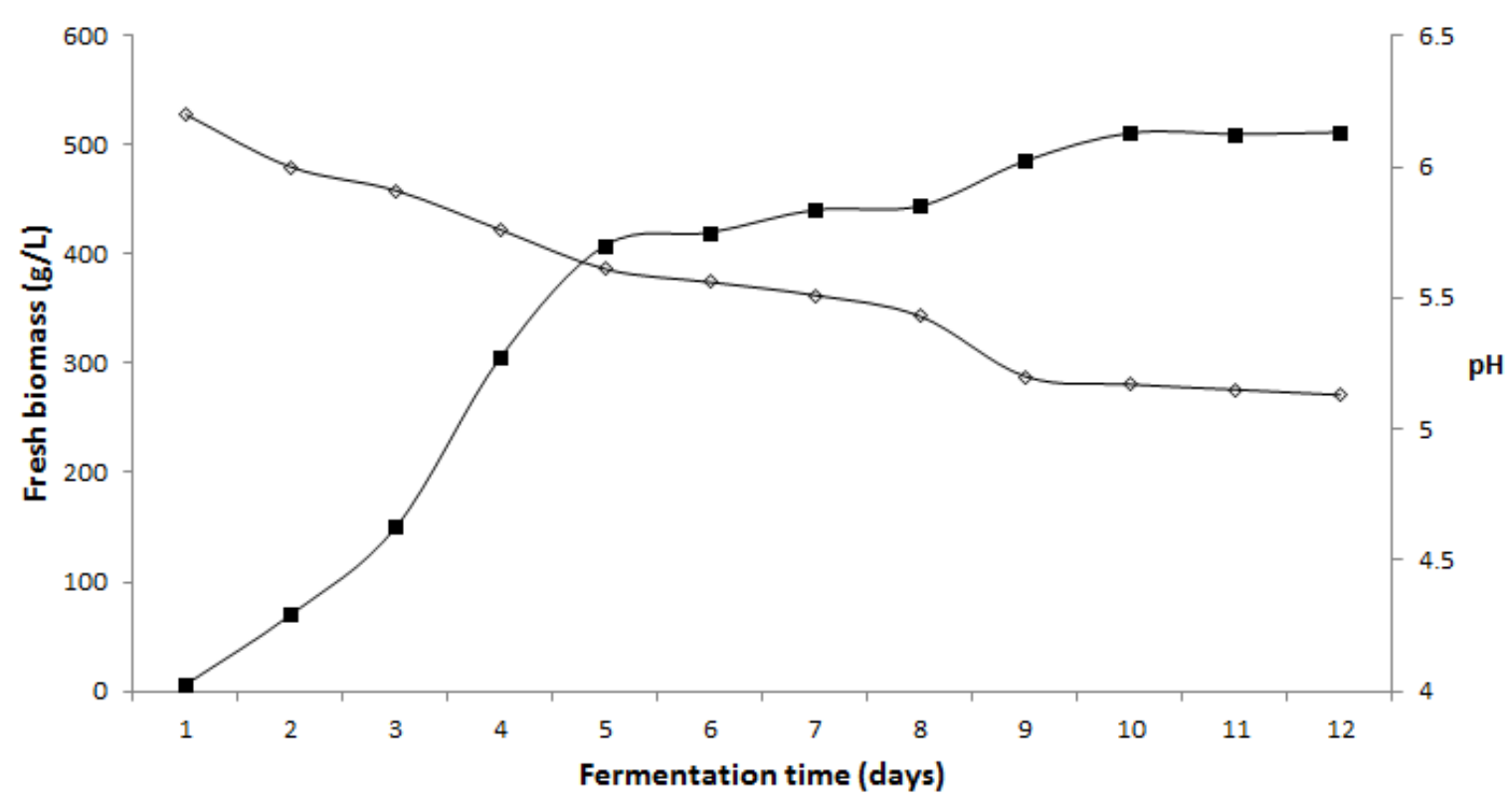

Figure 3. Evolution of fresh biomass (filled square) and $\mathrm{pH}$ (open diamond) during batch submerged fermentation (deproteinized CWP solution - 5\%) using Aspergillus oryzae.

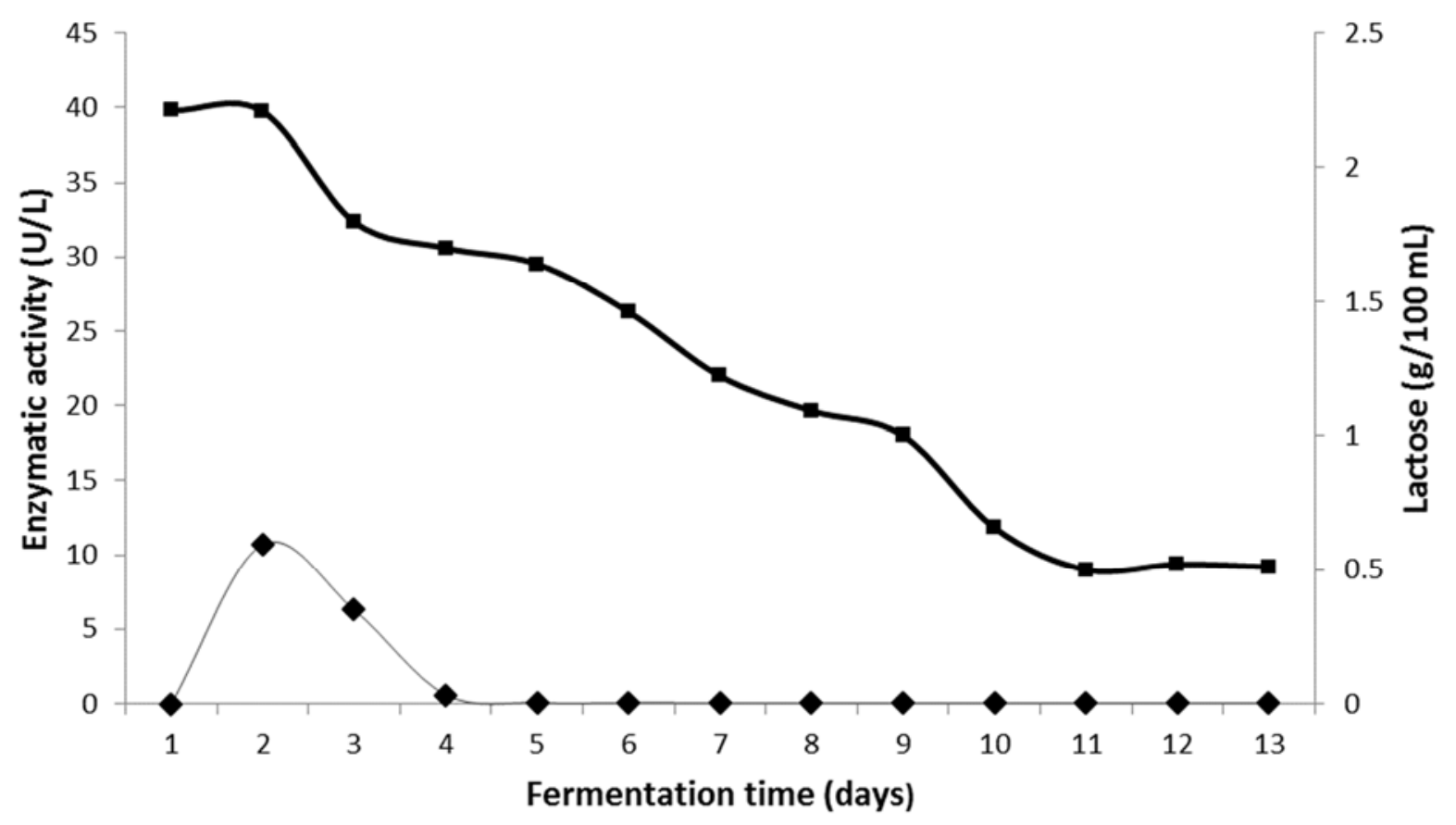

Figure 4. Evolution of enzymatic activity of $\beta$-galactosidase from Aspergillus oryzae and lactose content (filled square) during batch submerged fermentation (deproteinized and demineralized CWP solution - 5\%). 


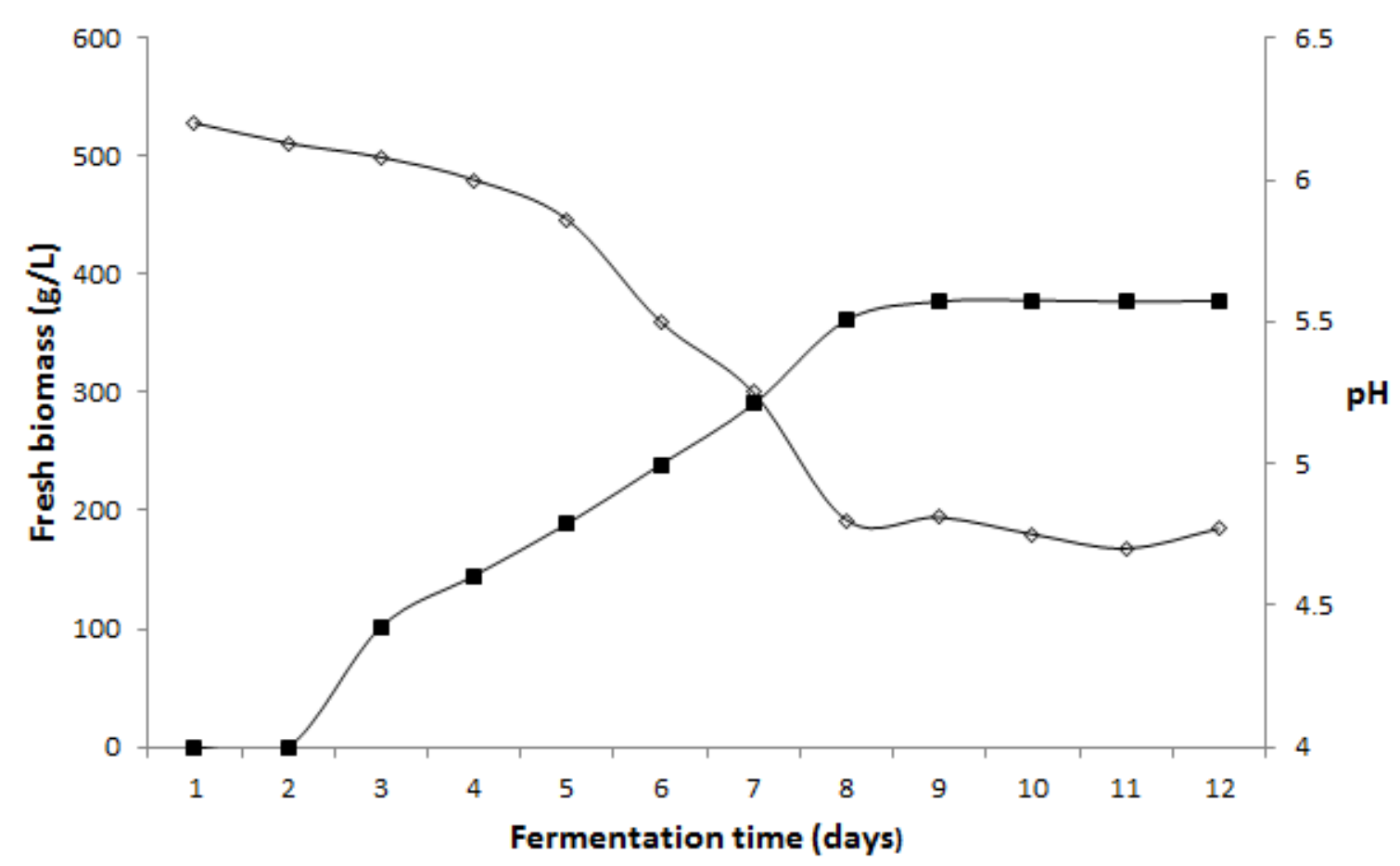

Figure 5. Evolution of fresh biomass (filled square) and $\mathrm{pH}$ (open diamond) during batch submerged fermentation (deproteinized and demineralized CWP solution - 5\%) using Aspergillus oryzae.

\section{CONCLUSION}

The production of value-added products such as $\beta$-galactosidase is an attractive option for cheese whey management. The results of this study indicate that deproteinization has beneficial effects on enzyme yield during the fermentation process of cheese whey. Moreover, the fermentation process was able to decrease the organic load (lactose content). These results may enable an alternative management of cheese whey, thereby decreasing its impact on environment.

\section{ACKNOWLEDGMENTS}

The authors are grateful for the support of Coordenação de Aperfeiçoamento de Pessoal de Nível Superior (CAPES), Fundação Nacional de Desenvolvimento do Ensino Superior Particular (FUNADESP), and Kroton Educational Company (KROTON).

\section{REFERENCES}

AOAC INTERNATIONAL. Official methods of analysis of AOAC international. Mayland, 2005.

ARAUJO, K. et al. Ethanol production from whey using fed-batch culture with repeated cycles. Interciencia, v. 40, n. 5, p. 305-310, 2015. http://www.interciencia.org/v40_05/indexe. html

BOSSO, A. et al. Lactose hydrolysis potential and thermal stability of commercial $\beta$ galactosidase in UHT and skimmed milk. Food Science and Technology, v. 36, n. 1, 2016. https://doi.org/10.1590/1678-457X.0085

\section{IPABH}

Rev. Ambient. Água vol. 12 n. 4 Taubaté - Jul. / Aug. 2017 
COLOGNESE, G. O. et al. Ethanol production potential of Saccharomyces fragilis IZ 275 using cheese whey powder solution. Agrociencia, v. 49, p. 291-298, 2015.

DANDOUH, L. et al. Rheological study of orange juices for a better knowledge of their suspended solids interactions at low and high concentration. Journal of Food Engineering, v. 174, p. 15-20, 2016. https://doi.org/10.1016/j.jfoodeng.2015.11.008

DE SANTIAGO-MARTIN, A. et al. Metal contamination disturbs biochemical and microbial properties of calcareous agricultural soils of the Mediterranean area. Archives of Environmental Contamination and Toxicology, v. 64, n. 3, p. 388-398, 2013. https://doi.org/10.1007/s00244-012-9842-8

DESCONSI, A.; IZÁRIO-FILHO, H.; SALAZAR, R. Physicochemical and microbiological evaluation of concentrated whey obtained by reverse osmosis. Revista Ambiente \& Agua, v. 9, n. 2, p. 325-335, 2014. https://doi.org/10.4136/ambi-agua.1316

DURAN, C. et al. Impact of suspended solids on the activated sludge non-Newtonian behaviour and on oxygen transfer in a bubble column. Chemical Engineering Science, v. 141, p. 154-165, 2016. https://doi.org/10.1016/j.ces.2015.10.016

FAN, Q. H. et al. Illuminating the binding interactions of galactonoamidines during the inhibition of beta-galactosidase (E-coli). Bioorganic \& Medicinal Chemistry, v. 24, n. 4, p. 661-671, 2016. https://doi.org/10.1016/j.bmc.2015.12.034

KROEGER, L.; THIEM, J. Synthesis and evaluation of glycosyl donors with novel leaving groups for transglycosylations employing beta-galactosidase from bovine testes. Carbohydrate Research, v. 342, n. 3-4, p. 467-481, 2007. https://doi.org/10. 1016/j.carres.2006.10.014

LEE, D. H. et al. Purification and characterization of a beta-galactosidase from peach (Prunus persica). Molecules and Cells, v. 15, n. 1, p. 68-74, 2003.

MALAKAR, P. et al. Effect on beta-galactosidase synthesis and burden on growth of osmotic stress in Escherichia coli. Springerplus, v. 3, p. 748, 2014. https://doi.org/10.1186/ 21931801-3-748

MIYAKE, Y. et al. Isolation of the antioxidant pyranonigrin-A from rice mold starters used in the manufacturing process of fermented foods. Bioscience Biotechnology and Biochemistry, v. 71, n. 10, p. 2515-2521, 2007. https://doi.org/10.1271/bbb.70310

MOREIRA, N. L. et al. Dynamics of ethanol production from deproteinized whey by Kluyveromyces marxianus: An analysis about buffering capacity, thermal and nitrogen tolerance. Brazilian Archives of Biology and Technology, v. 58, n. 3, p. 454-461, 2015. https://doi.org/10.1590/S1516-8913201500372

MURTHY, P. S.; SUZUKI, S.; KUSUMOTO, K.I. Effect of light on the growth and acid protease production of Aspergillus oryzae. Food Science and Technology Research, v. 21, n. 4, p. 631-635, Jul. 2015. http://doi.org/10.3136/fstr.21.631

PACHECO, F. et al. Preliminary study of the enzymatic activity of native isolates of entomopathogenic fungi from the citrus area of Mexico in solid culture media. Journal of Pure and Applied Microbiology, v. 9, n. 1, p. 579-585, 2015. 
SAVAIANO, D. A. et al. Improving lactose digestion and symptoms of lactose intolerance with a novel galacto-oligosaccharide (RP-G28): a randomized, double-blind clinical trial. Nutrition Journal, v. 12, p. 160, 2013. https://doi.org/10.1186/1475-2891-12-160

SUZUKI, C. et al. Lipid-rich bovine serum albumin improves the viability and hatching ability of porcine blastocysts produced in vitro. Journal of Reproduction and Development, v. 62 , n. 1, p. 79-86, 2016. http://doi.org/10.1262/jrd.2015-076

TUNICK, M. H.; VAN HEKKEN, D. L. Dairy products and health: Recent insights. Journal of Agricultural and Food Chemistry, v. 63, n. 43, p. 9381-9388, nov. 2015. https://doi.org/10.1021/jf5042454

YAN, L. Q.; LI, N.; ZONG, M. H. First enzymatic galactosylation of acyclic nucleoside drugs by beta-galactosidase: Synthesis of water-soluble beta-D-galactosidic prodrugs. Biotechnology and Bioprocess Engineering, v. 19, n. 4, p. 586-591, jul. 2014. https://doi.org/10.1007/s12257-013-0823-1 